\title{
Potential Development Strategy for Attraction and Community- based Agrotourism in Lebakmuncang Village
}

\author{
$E$ Djuwendah $^{1 *}, T$ Karyani $^{1}$, and $E$ Wulandari ${ }^{1}$ \\ ${ }^{1}$ Agribusiness Study Program, Faculty of Agriculture, Universitas Padjadjaran, Indonesia
}

\begin{abstract}
Lebakmuncang is a tourism village in Ciwidey, Bandung, West Java, Indonesia, which has potential for natural and cultural resources supporting agro-tourism development. In recent years there has been a decline in tourist visits. The research objectives were to analyze the agro-tourism potential, to analyze visitor's perceptions of the attractiveness of agro-tourism and agro-tourism development strategies. The research design used descriptive quantitative. Fifty tourists were selected by accidental sampling, and ten informants were selected purposively. Data analysis technique used Likert scale and SWOT matrix. The results showed Lebakmuncang village has variety agricultural commodities, dairy farming, and coffee processing business that have potential to support agro-tourism development; visitors' perceptions of attraction and ancillary services was excellent. Visitors' perception of amenities and accessibility was good. Strategies that can be carried out in developing agro-tourism are: (1) increasing community involvement, (2) adding animal husbandry attractions and coffee processing in tour packages, (3) adding supporting facilities that are not yet available, (4) synchronizing agro-tourism development programs with stakeholders, (5) training human resources in internet technology-based tourism management, (6) partnerships in promotion and marketing with travel agents, (7) improving service quality, (8) creating community-based and sustainable agro-tourism branding, and (9) promotional cooperation with other tourist objects..
\end{abstract}

\section{Introduction}

Tourism is an economic and service sector with the highest growth rate globally $[1,2]$. The WTTC (World Travel and Tourism Council) report in 2017 shows that tourism accounts for up to $10 \%$ of the world's total GDP (Gross Domestic Product). Job creation, one in ten workers, is created due to tourism activities [3].

The current development of tourism trends leads to back to nature $[4,5]$. This concept is formed because humans are part of nature, and the natural atmosphere is seen as a suitable place of entertainment to relax from daily routines. One of the tours with a back to nature concept that can be developed in Indonesia is agrotourism, a series of tourism businesses by utilizing agricultural potential as its object with the aim of recreation, additional knowledge, and knowing business relationships in agriculture [6].

Agro-tourism is a diversified tourism product that combines agricultural (agro) and recreational activities in an agricultural environment [7]. Agro-tourism is a small-scale business activity managed by a family or cooperative and developed in rural areas by people who work in agriculture [8]. Agro-tourism is a tourism activity that utilizes agricultural business as a tourist attraction. It aims to expand knowledge, recreational experience, and business relations in agriculture. Through agro-tourism that emphasizes local culture in utilizing land, farmers' income can increase and efforts to conserve land resources and maintain local culture and technology (indigenous knowledge), which are generally following their natural environmental conditions [9]. Agro-tourism also provides opportunities for tourists to engage in rural recreational activities to broaden their knowledge, recreational experience, and business relations in the agro-sector.

West Java is one of the provinces with many attractive natural tourist destinations, making it the primary destination for domestic and international tourists. One of the West Java areas that offers a variety of agro-tourism potential is the South Bandung tourism area. Lebakmuncang Village is one of the tourist villages established by the Bandung Regency Government in 2011. Moreover, the community manages this tourist village with guidance from the Bandung district culture and tourism office. The uniqueness of the village of Lebakmuncang is a combination of natural and cultural beauty. The tourism concept developed is based on agriculture, environment, and culture. Visitors can enjoy nature's beauty and take part in the community's daily activities to learn about agriculture, art, and culture and enjoy traditional culinary delights. The tourist attractions offered include agricultural education, outdoor activity programs, cultural interactions, culinary tourism activities (education specialties), and homestays.

The tourism industry produces products and services specifically aimed at meeting the needs of

* Corresponding author: endah.djuwendah@ unpad.ac.id 
tourists [10]. Tourism products and services are tourism potential, but other elements form a unity in tourism products, namely accessibility, amenities, and hospitality [11]. Tourists' perception of consuming products and services while tourists visit a destination will be influenced by differences in facilities, tourist attractions, and services in each destination [12]. The three components of tourism products available in a destination can satisfy the needs and desires of tourists [13].

The development of tourism in an area can be seen from the number of tourists visiting these attractions. In the last three years, the number of visitors to Lebakmuncang Tourism Village has fluctuated. In 2017, the number of visitors increased from 566 people in 2016 to 762 people. Meanwhile, in 2018, the number of visitors has decreased to 688 people [14]. This evidence is probably due to the potential for tourist attraction in the village of Lebakmuncang and the development of agro-tourism in other similar areas. Therefore, Lebakmuncang Tourism Village's management needs to know visitors' perceptions to the potential of agrotourism and carry out appropriate development strategies to increase its existence..

\section{Materil and Methods}

Lebakmuncang village agro-tourism experiences dynamics in its development, so it is interesting to research. The purpose of this study was to identify the potential of agro-tourism, see the visitor's perception of the attractiveness of agro-tourism, and analyze agrotourism development strategies in the village of Lebakmuncang. The object of research is the potential attractiveness of agro-tourism and agro-tourism development strategies. The research method used is a case study. The variables studied were the potential attractiveness of agro-tourism, visitor perceptions of agrotourism potential attractiveness, and agro-tourism development strategies.

This study uses primary data and secondary data. Primary data is taken directly through field observations, interviews with visitors using questionnaires, and in-depth interviews with community leaders. Respondents in this study were 50 visitors who were selected by accidental sampling. At the same time, the key informants were selected purposively from 8 agro-tourism managers and community leaders. The data analysis technique was carried out descriptively.

Visitor perceptions were analyzed using a Likert scale, and agro-tourism development strategies were analyzed using SWOT. SWOT analysis uses strengths to overcome weaknesses and take advantage of every opportunity while removing all threats to get various alternative development strategies [15]. The SWOT analysis results provide several alternative strategies that are adopted based on logic to achieve goals [16].

\section{Result}

\subsection{The potential attraction of agro-tourism in the village of Lebakmuncang}

Lebakmuncang tourism village is a tourist area located between Geulis and Mount Guruyung, Ciwidey District, Bandung Regency, West Java. Lebakmuncang village tourism activity is categorized as agro-tourism with an agricultural and cultural education orientation. Lebakmuncang tourism object is managed directly by the Lebakmuncang Workers Group (POKJA) and is assisted by the culture and tourism of Bandung Regency. Lebakmuncang rural tourism is at an altitude of \pm 1200 meters above sea level with upland topography and rainfall of 2,150 $\mathrm{mm}$ per year and has an average temperature of 18-20 degrees Celsius [17].

Agricultural commodities cultivated by farmers in Lebak Muncang Village are very diverse in horticultural crops and plantation crops. Horticultural commodities grown include onions, tomatoes, cauliflower, chilies, celery, and strawberries. Plantation crops that are cultivated are coffee and tea. There are dairy farming, beef cattle and potato chips agro-industry, coffee and chests, and strawberry jam. Lebak Muncang tourism village offers a variety of agro-tourism, namely farming. Outdoor activity program and cultural education. The potential of Lebakmuncng village agro-tourism is presented in Table 1.

Table 1. The potential attraction of agro-tourism in Lebakmuncang village

\begin{tabular}{|c|c|c|}
\hline $\begin{array}{l}\text { Potential } \\
\text { tourism }\end{array}$ & $\begin{array}{l}\text { Tourist } \\
\text { attraction }\end{array}$ & $\begin{array}{l}\text { Tourism } \\
\text { Activity }\end{array}$ \\
\hline $\begin{array}{l}\text { Agricultural } \\
\text { education }\end{array}$ & $\begin{array}{l}\text { Strawberry } \\
\text { cultivation, } \\
\text { tomato } \\
\text { cultivation, } \\
\text { vegetable } \\
\text { cultivation, } \\
\text { dairy cow } \\
\text { farming }\end{array}$ & $\begin{array}{l}\text { Earn to cultivate the } \\
\text { land, plant and } \\
\text { harvest tomatoes } \\
\text { and strawberries, } \\
\text { and milk the cows }\end{array}$ \\
\hline $\begin{array}{l}\text { Outdoor } \\
\text { activity } \\
\text { program }\end{array}$ & $\begin{array}{l}\text { Jungle trekking } \\
\text { and } \\
\quad \text { cycling } \\
\text { around the } \\
\text { village }\end{array}$ & $\begin{array}{l}\text { Walking through } \\
\text { the hilly area, } \\
\text { enjoying the } \\
\text { scenery and rural } \\
\text { atmosphere }\end{array}$ \\
\hline $\begin{array}{l}\text { Cultural } \\
\text { interaction }\end{array}$ & $\begin{array}{l}\text { Cultural arts } \\
\text { performances }\end{array}$ & $\begin{array}{l}\text { Watching } \\
\text { jaipongan, pencak } \\
\text { silat, } \\
\text { angklung }\end{array}$ \\
\hline $\begin{array}{l}\text { Education } \\
\text { specialties }\end{array}$ & $\begin{array}{l}\text { Learn and enjoy } \\
\text { local traditional } \\
\text { culinary }\end{array}$ & $\begin{array}{l}\text { Learn to make } \\
\text { traditional foods } \\
\text { made from local } \\
\text { ingredients such as } \\
\text { Jenar crackers, } \\
\text { crispy mushrooms, } \\
\text { sweet potato } \\
\text { chopsticks, candied } \\
\text { papaya, dodol nuts, } \\
\text { etc. }\end{array}$ \\
\hline
\end{tabular}

Based on the data in Table 1, the tourist objects that take place in the village of Lebak Muncang are quite 
varied. The tour packages offered are agricultural education, outdoor activity program; cultural interactions; and educational specialties [8]. Compared to the existing potential, the tour packages offered are still lacking. The cultivation and processing of coffee and cattle farming have not been packaged and included in the tour package. Coffee processing and animal husbandry can provide attractive environmental and health conservation education for tourists.

\subsection{Visitor perceptions of Lebakmuncang Village Agro tourism attraction data}

The visitor's perception of agrotourism attractiveness using the components of attraction, amenities, accessibility, and ancillary [19, 13].

Tabel 2. Visitor perceptions of the attractiveness of Lebakmuncang agro-tourism

\begin{tabular}{|c|c|c|c|}
\hline Component & Indicator & $\begin{array}{l}\text { Perception } \\
\text { score }\end{array}$ & Category \\
\hline Attraction & $\begin{array}{l}\text { Beautiful } \\
\text { and } \\
\text { comfortable } \\
\text { rural natural } \\
\text { conditions } \\
\text { diversity of } \\
\text { traditional } \\
\text { foods and } \\
\text { drinks } \\
\text { diversity } \\
\text { of farming } \\
\text { education }\end{array}$ & 365 & very good \\
\hline Amenities & $\begin{array}{l}\text { Availability } \\
\text { of parking } \\
\text { facilities, } \\
\text { public } \\
\text { toilets, } \\
\text { places of } \\
\text { worship, } \\
\text { restaurants, } \\
\text { performance } \\
\text { halls, } \\
\text { gazebos, and } \\
\text { homestays }\end{array}$ & 845 & good \\
\hline Accessibility & $\begin{array}{l}\text { Road } \\
\text { conditions, } \\
\text { availability } \\
\text { of signs and } \\
\text { directions as } \\
\text { well as an } \\
\text { easily } \\
\text { accessible } \\
\text { location }\end{array}$ & 318 & good \\
\hline $\begin{array}{l}\text { Ancillary } \\
\text { services }\end{array}$ & $\begin{array}{l}\text { Availability } \\
\text { of electricity } \\
\text { network, } \\
\text { clean water } \\
\text { network and } \\
\text { internet } \\
\text { network }\end{array}$ & 390 & very good \\
\hline
\end{tabular}

Tourism attractiveness and service facilities together affect tourist satisfaction and return visits [20]. The concept of tourist attractions presented by agrotourism in Lebaknucang village with indicators of beautiful, beautiful, and clean natural conditions, various special culinary presentations, and educational tourism products were rated very well by visitors with a score of 365. This result is due to the natural environment conditions of Lebakmuncang Village are still natural; traditional has cultural attractions and natural rural area layout architecture. Lebakmuncang tourism village offers educational tour packages, cultural education, and social education.

The visitors' perceptions about the amenities and accessibility showed good categories. Facilities and infrastructure that are not optimally available, limited in number, and less strategic layout are toilets, trash bins, and food stalls. The accessibility observations show that Lebakmuncang Village has a strategic location and is easy to access. Lebakmuncang Village is located in a hilly area with a large agricultural area traversed by uphill, asphalt roads and a width of 5-6 meters. The opening of the Soroja toll highway in 2017 made it easier to access the tourist village of Lebakmuncang, which is about $50 \mathrm{~km}$ from the center of Bandung City and can be reached in about one hour. Ancillary services are supporting facilities that help determine the success of the agro-tourism business. Twenty tour guides come from residents. There is a Tourism Information Center that functions as a forum for tourism activities [17]. Electricity, clean water, and internet networks are also available. The visitor's perception of ancillary services shows an outstanding category.

\subsection{Lebakmuncang Village Agro-tourism Development Strategy}

The alternative formulation of the agro-tourism strategy in Lebakmuncang village was carried out using SWOT analysis. In the SWOT analysis, alternative strategies are divided into four, namely the S-O strategy (strength-opportunities), W-O strategy (weaknessesopportunities), S-T strategy (strength-threats), W-T strategy (weaknesses-threats) [21]. From the strategy formulation in the SWOT matrix, 9 alternative strategies were produced according to internal and external factors for increasing competitiveness, which can be seen in Table 3.

Table 3. The potential attraction of agro-tourism in Lebakmuncang village

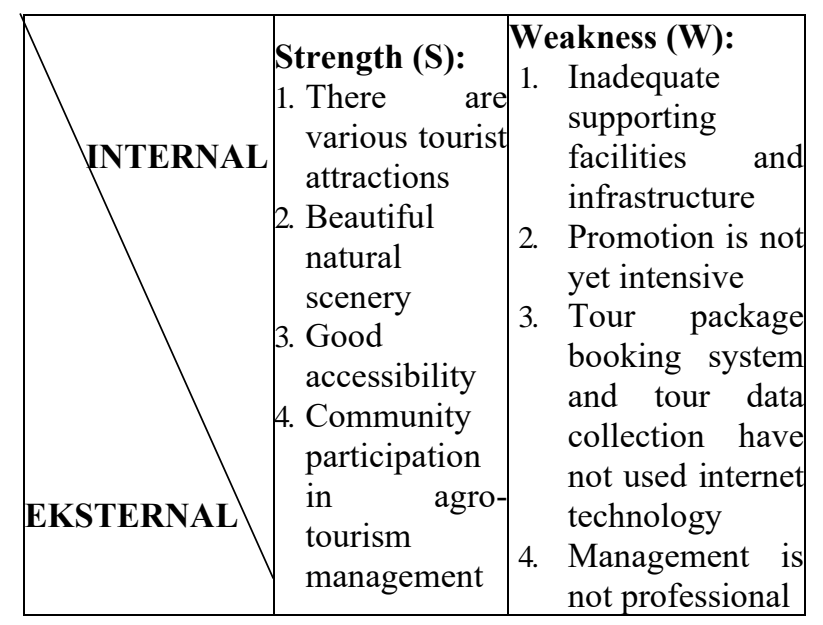




\begin{tabular}{|c|c|c|}
\hline & $\begin{array}{l}\text { 5. There is a } \\
\text { large area } \\
\text { available for } \\
\text { agro-tourism } \\
\text { development }\end{array}$ & \\
\hline \begin{tabular}{|l|} 
Opportunity \\
(O): \\
1. Back to nature \\
tourism trend \\
2. Dairy cattle \\
and coffee \\
cultivation are \\
potential \\
tourist \\
attractions \\
3. Digital \\
technology \\
that facilitates \\
tourism \\
transactions \\
and \\
promotions \\
4. The \\
development \\
of a travel \\
agency \\
5. There is a \\
tourism \\
village \\
development \\
program from \\
the \\
government \\
6. Strategic \\
location in the \\
tourist area of \\
South \\
Bandung \\
\end{tabular} & $\begin{array}{l}\text { SO Strategy: } \\
\text { 1. Adding dairy } \\
\text { farming, } \\
\text { cultivation, } \\
\text { and coffee } \\
\text { agro- } \\
\text { industry as } \\
\text { tourist } \\
\text { attractions in } \\
\text { the tour } \\
\text { package } \\
\text { 2. Optimizing } \\
\text { the } \\
\text { arrangement } \\
\text { of agro- } \\
\text { tourism areas }\end{array}$ & $\begin{array}{l}\text { WO Strategy: } \\
\text { 1. Complete } \\
\text { supporting } \\
\text { facilities and } \\
\text { infrastructure } \\
\text { 2. Synchronization } \\
\text { of stakeholder } \\
\text { work programs } \\
\text { that support agro- } \\
\text { tourism } \\
\text { development } \\
\text { 3. Training on the } \\
\text { use of IT in } \\
\text { tourism } \\
\text { management and } \\
\text { marketing } \\
\text { 4. Partnering with } \\
\text { travel agents in } \\
\text { tourism } \\
\text { promotion }\end{array}$ \\
\hline \begin{tabular}{|l|} 
Threat (T): \\
1. Competition \\
with other agro- \\
tourism in tourist \\
areas \\
2. The uniqueness \\
and uniqueness of \\
agro-tourism as \\
competitiveness \\
3. The awareness \\
of tourists to \\
protect tourist \\
objects
\end{tabular} & $\begin{array}{l}\text { ST Strategy: } \\
\text { 1. Building } \\
\text { branding as } \\
\text { an agro- } \\
\text { ecotourism } \\
\text { village }\end{array}$ & $\begin{array}{l}\text { WT Strategy: } \\
\text { 1. Cooperating } \\
\text { with other tourist } \\
\text { attractions in } \\
\text { promotion } \\
\text { 2. Improve the } \\
\text { quality of agro- } \\
\text { tourism services } \\
\text { to increase } \\
\text { visitor } \\
\text { satisfaction }\end{array}$ \\
\hline
\end{tabular}

Based on SWOT analysis listed in Table 2, in general, the main strategies in the development of agrotourism in Lebak Muncang village are:

1. Increase the diversity of tourist attractions by Adding dairy farming, cultivation, and coffee agro-industry as tourist attractions in the tour package

2 Optimizing the arrangement of the agrotourism area

3. Complete supporting facilities and infrastructure
4. Synchronization of stakeholder programs that support agro-tourism development

5. Training on the use of IT in tourism management and marketing

6. Partnering with travel agents in tourism promotion

7. Cooperating with other tourist attractions in promotion

8. Improve the quality of agro-tourism services to increase visitor satisfaction

9. Building branding as an agro-ecotourism village in order to increase competitiveness and visitor satisfaction.

\section{Conclusion}

Lebakmuncang tourist village has various agro-tourism attractions. The potential attraction of agro-tourism in Lebakmunvcang Village is the beauty of rural natural atmosphere with the primary commodities of horticulture and animal husbandry and cultural diversity in the form of arts culinary. The potential of agrotourism is presented in tour packages containing agricultural education (agro-pharmaceutical), trekking, cycling, education on traditional culinary processing, and the arts. Agro-tourism management refers to the concept of tourism-based community empowerment. The perception of visitors to the attractiveness of agrotourism in Lebakmuncang village shows excellent conditions in the attractions, ancillaries, and amenities.

\section{Acknowledgment}

The authors would like to thank Padjadjaran University (UNPAD) especially for the directorate of community service research and innovation, which has funded this research through internal grant by the Unpad lecturers' dissemination research program (RDDU) in 2020.

\section{References}

1. Bechard, A. Harmful algae, 85 (2019)

2. Khasanov, I. S., Procedia Economics and Finance, 24:313-317 (2015)

3. United Nations and World Tourism Organization. UNWTO tourism highlight 2018 edition. (2018)

4. Fendrychová, L., \& Jehlička, P., Geoforum, 95, 110 (2018).

5. Kisgyörgy, L., \& Vasvári, G., Case Studies on Transport Policy, 5(3), 453-459. (2017)

6. Saputra, G. B., Muksin, M., \& Muspita, M., Jurnal Ekonomi Pertanian dan Agribisnis, 2(4), 325-331 (2018)

7. Sznajder L, Prezezborska F, dan Scrimgeour, Agritourism (2009)

8. Kizos, T., \& Iosifides, T., South European Society \& Politics, 12(1), 59-77 (2007)

9. Sastrayuda, G. S., UPI, (2010)

10. Zaenuri, M., Jogjakarta: e-Gov Publishing, (2012). 
11. Damanik J dan Weber H.F., Penerbit Andi Yogyakarta, (2006)

12. Laws, E.. Tourist destination management: issues, analysis and policies. Routledge (1995)

13. Yoeti, Oka A. Perencanaan dan Pengembngan Pariwisata PT Pasdya Pramita, Jakarta (2008)

14. Siregar, S. D., Djuwendah, E., Rasmikayati, E., \& Wiyono, S. N., Jurnal Pemikiran Masyarakat Ilmiah Berwawasan Agribisnis. Juli, 6(2), 542-553 (2020)

15. Chan, X. A ., International Journal of Business and Social Science, 2(11) (2011)

16. Ikhsan, S., Aid, A., \& Pertanian, S. P. J. S. E., Jurnal Agribisnis Pedesaan, 1(3), 166-177 (2011)

17. Raharja, S. U. J., Marbun, M., \& Chan, A., Sosiohumaniora, 21(2), 159-165 (2019)

18. Pratama, F. G., \& Kurnia, G., Jurnal Ilmiah Mahasiswa Agroinfo Galuh, 5(1), 1014-1028 (2018)

19. Cooper, C. (2008). Tourism: Principles and practice. Pearson education (2019)

20. Cooper, Fletcher, J. Gilbert D and Wanhill, S Tourim, Prinsiple and practise. London, Longman (1993)

21. Aprilia, E. R. Pengaruh daya tarik wisata dan fasilitas layanan terhadap kepuasan wisatawan di Pantai Balekambang Kabupaten Malang (Doctoral disertation, Universitas Brawijaya) (2017)

22. David F.R. Strategic Managemant. Konsep Manajemen Strategis, E 12 (2012). 